\title{
Polychlorinated biphenyls (PCBs) and polybrominated biphenyl ethers (PBDEs) in environmental samples from Ny-Ålesund and London Island, Svalbard, the Arctic
}

\author{
Chaofei Zhu ${ }^{a}$, Yingming Li ${ }^{a}$, Pu Wang ${ }^{a}$, Zhaojing Chen ${ }^{a}$, Daiwei Ren ${ }^{a}$, Patrick Ssebugere ${ }^{b}$, \\ Qinghua Zhang ${ }^{\mathrm{a}, *}$, Guibin Jiang ${ }^{\mathrm{a}}$
}

a State Key Laboratory of Environmental Chemistry and Ecotoxicology, Research Center for Eco-Environmental Sciences, Chinese Academy of Sciences, Beijing 100085, China

${ }^{\mathrm{b}}$ Department of Chemistry, Makerere University, P.O. Box 7062, Kampala, Uganda

\section{H I G H L I G H T S}

- PCBs including chiral compounds and PBDEs were investigated in various matrices from Arctic region.

- $\mathrm{CB}-11$ was the major contributor of the total PCBs concentration.

- The concentrations of PCBs and PBDEs are at very low levels in the soil, plants and reindeer dung.

- Bioaccumulation factors of PCBs in six plants were less than 1, whereas those of PBDEs were higher than 1.

\section{A R T I C L E I N F O}

\section{Article history:}

Received 18 July 2014

Received in revised form 15 December 2014

Accepted 26 January 2015

Available online 17 February 2015

Handling Editor: H. Fiedler

\section{Keywords:}

PCBs

PBDEs

Soil

Plants

Arctic

\begin{abstract}
A B S T R A C T
Polychlorinated biphenyls (PCBs) and polybrominated biphenyl ethers (PBDEs) were determined in environmental samples collected from Ny-Ålesund and London Island, Svalbard, the Arctic. Total PCB concentrations ( $\sum_{25} \mathrm{PCBs}$ ) varied from 0.57 to $2.52 \mathrm{ng} \mathrm{g}^{-1}$ dry weight $(\mathrm{dw})$ in soil, 0.30 to $1.16 \mathrm{ng} \mathrm{g}^{-1} \mathrm{dw}$ in plants and 0.56 to $0.98 \mathrm{ng} \mathrm{g}^{-1} \mathrm{dw}$ in reindeer dung. The non-Aroclor congener of $\mathrm{CB}-11$ was predominant in most samples compared to other congeners, accounting for $16.0 \pm 9.8 \%$ to the $\sum_{25} \mathrm{PCBs}$. The $\sum_{13} \mathrm{PBDEs}$ concentrations were 1.7-416, 36.7-495 and 28.1-104 $\mathrm{pg} \mathrm{g}^{-1} \mathrm{dw}$ in soil, plants and reindeer dung, respectively. The signature of enantioselective biotransformation was observed in all samples for chiral CB-95, whereas in parts of samples for other chiral PCBs. Bioaccumulation factors (BAFs) in six plant species varied within individual contaminant congeners and plant species, with BAFs less than 1 for $\sum$ PCBs and higher than 1 for $\sum$ PBDEs. BAF values decreased with increasing soil concentrations, suggesting that high background levels in soil restricted the accumulation of these contaminants by plants.
\end{abstract}

(c) 2015 Elsevier Ltd. All rights reserved.

\section{Introduction}

Arctic ecosystems, without significant human activities and emission sources, are subject to potential contamination of various agricultural, industrial chemicals and their by-products (Corsolini et al., 2002; McKinney et al., 2011). Persistent organic pollutants (POPs) such as polychlorinated biphenyls (PCBs) and polybrominated diphenyl ethers (PBDEs) have been widely detected in various environmental media and biota in the Arctic (Muir and Norstrom, 2000; Ikonomou et al., 2002; de Wit et al., 2006; Ross et al., 2008). A number of studies pointed out long-range atmospheric transport, ocean currents and precipitation as

\footnotetext{
* Corresponding author. Tel./fax: +86 1062849818

E-mail address: qhzhang@rcees.ac.cn (Q. Zhang).
}

possible pathways of these pollutants in the Arctic (Fisk et al. 2002; Braune et al., 2007).

PCBs were widely used as dielectric fluids in transformers and capacitors in the $1960 \mathrm{~s}$, but their production and use was banned in the late 1970s due to persistent nature in the environment and adverse effect on human's health (Muir and Norstrom, 2000; Ockenden et al., 2003; Choi et al., 2008). Of the 209 РСB congeners, the twelve dioxin-like and six indicator PCBs were usually concerned due to their high toxicity and high concentrations in the environment. In recent years, 3,3'-dichlorobiphenyl (CB-11), an non-Aroclor PCB congener, has attracted great attention due to its ubiquitous presence and specific potential emission sources associated with pigment yellow production (Choi et al., 2008; Ross et al., 2008; Lehmler et al., 2009; Shang et al., 2014). 
Signature of chiral PCBs provide a useful tool to investigate biotransformation mechanisms of PCBs (Dang et al., 2010). Chiral pollutants exist in two forms as optical isomers, called enantiomers (Fisk et al., 2002). Although the two enantiomers have identical physical and chemical properties, they present different biological and toxicological effects in mammals (Ross et al., 2008; Lehmler et al., 2009). They are frequently observed as nonracemic mixtures in various organisms tissues (Ross et al., 2008; Zhai et al., 2011). To our knowledge, knowledge on the enantioselective biotransformation of chiral PCBs in the Arctic environments is still scarce.

PBDEs are man-made brominated flame retardants used in a wide range of consumption products such as insulation materials, electronic equipments and furniture (Herzke et al., 2003; Yogui and Sericano, 2008). Since PBDEs were first reported in 1987 in muscle tissues of animals collected in the Baltic Sea, North Sea and Arctic Ocean (Jansson et al., 1987), they were widely detected in various environmental media and different regions including the Arctic (de Wit et al., 2010; McKinney et al., 2011). PBDEs present comparable toxicological behavior with PCBs based on available toxicity data and chemical structures (McDonald, 2002). As endocrine disruptors, PBDEs can cause neurobehavioral deficits and cancer in animals (Ikonomou et al., 2002; McDonald, 2002). They could also transfer between different matrices (such as from soil to plant), bioaccumulate strongly in adipose tissues and biomagnify through the food chains (Hargrave et al., 2000; Corsolini et al., 2002; Pier et al., 2002).

Plants are indicative of deposition from air, providing evidence of long-range transport (de Wit et al., 2006). A certain of plants have a high lipid fraction to accumulate lipophilic compounds from air precipitates and therefore play an important role in the global cycling of contaminants (Lead et al., 1996). Soils are considered as a sink for toxic chemicals. Therefore, they are influential for fate and distribution of POPs in the global scale (Negoita et al., 2003; Ockenden et al., 2003). In this study, soils, plants and reindeer dung samples were collected in Ny-Ålesund and London Island, Svalbard, the Arctic, to investigate the current contamination levels and spatial distribution of PCBs and PBDEs. Enantioselective biotransformation of PCBs and bioaccumulation of PCBs and PBDEs from soil to plant were also discussed.

\section{Materials and methods}

\subsection{Sample collection}

Environmental samples were collected from Ny-Ålesund and London Island, Svalbard, the Arctic, between September 2011 and September 2012. Details of the longitude and latitude for all sampling sites are presented in Table S1 (see Supplementary material). A total of 36 samples, including 10 moss (Drepanocladus aduncus), 1 tufted saxifrage (Saxifraga cespitosa), 3 arctic bell-heather (Cassiope tetragona), 3 mountain avens (Dryas octopetala), 4 sooty sedge (Carex misandra), 2 Alpine hair grass (Deschampsia alpine), 6 reindeer dung, and 7 soil samples, were collected at different sites (Fig. 1). The samples were wrapped in aluminum foil, transferred into a polyethylene bags with a zip locks and labeled with a permanent marker. They were then transported to the laboratory and kept in a freezer maintained at $-20^{\circ} \mathrm{C}$ prior to extraction.

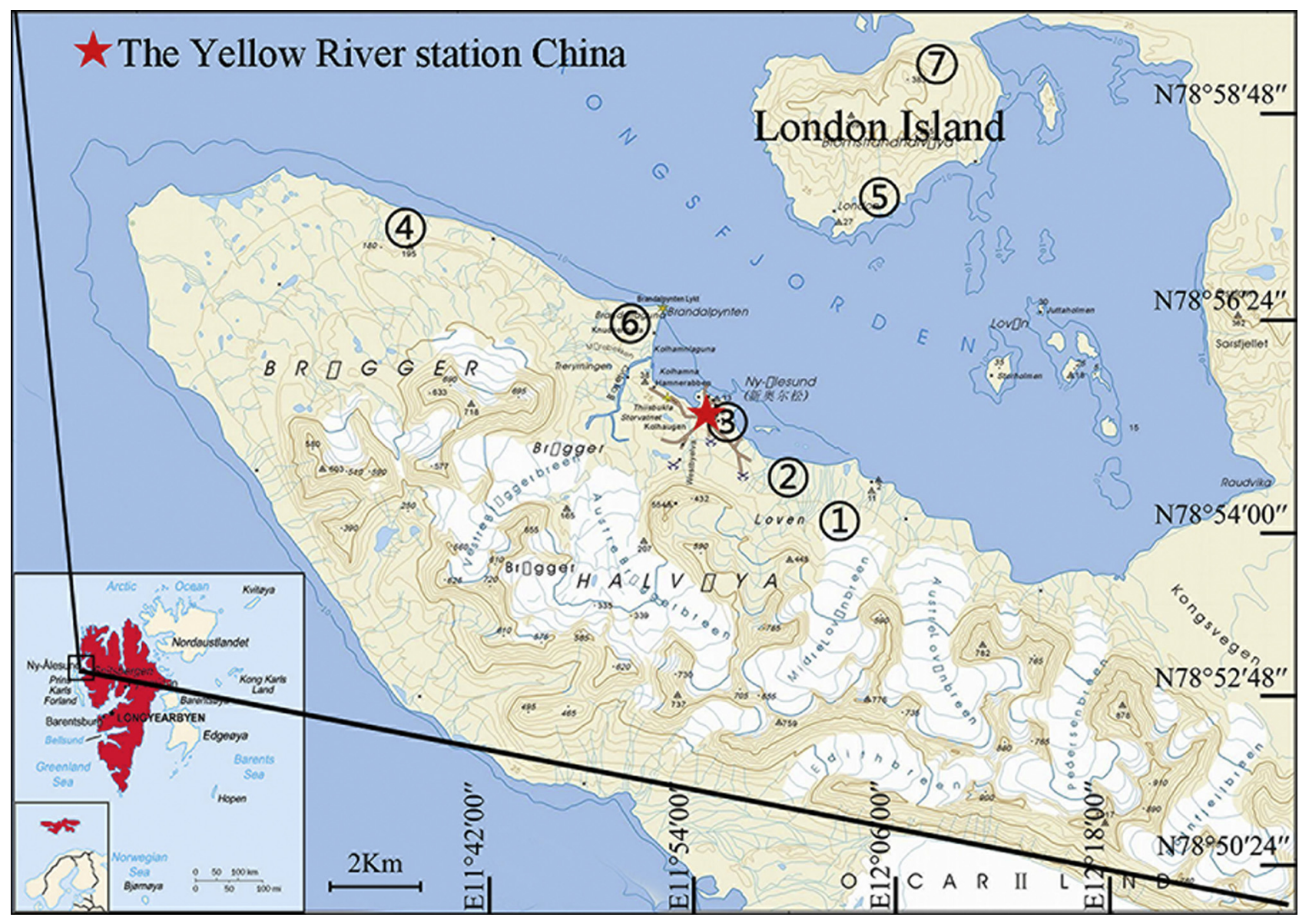

Fig. 1. Distribution of the sampling sites in Ny-Ålesund and London Island, Arctic. 


\subsection{Standards, reagents and chemicals}

Standard solutions of PCBs (US EPA defined 68A-LCS, 68A-IS), and PBDEs (BDE-LCS, ${ }^{13} \mathrm{C}-\mathrm{BDE}-47,-99$, and -153) were all obtained from Wellington Laboratories (Guelph, Ontario, Canada). Pesticidegrade solvents, dichloromethane (DCM), n-hexane, toluene and acetonitrile (HPLC-grade) were purchased from J.T. Baker Company Inc. (Fairfield, OH, USA). Silica gel $60(0.063-0.100 \mathrm{~mm})$ was obtained from Merck (Darmstadt, Germany). $\mathrm{C}_{18}$ reversed-phase SPE columns ( $3 \mathrm{~mL}, 20 \mu \mathrm{m}$ porosity) were bought from Supelco Inc. (Bellefonte, PA, USA). The carbon mixture $(18 \% w: w)$ was prepared using $9 \mathrm{~g}$ carbon (Carbopak C, Supelco 10258, USA) dispersed $41 \mathrm{~g}$ Celite (545 coarse, Fluka 22140, USA). Anhydrous sodium sulfate, concentrated sulfuric acid and sodium hydroxide were of guaranteed grade from the domestic market. Prior to use, silica gel, and anhydrous sodium sulfate and carbon mixture were baked at $550{ }^{\circ} \mathrm{C}$ for $12 \mathrm{~h}$, at $660^{\circ} \mathrm{C}$ for $6 \mathrm{~h}$ and at $130^{\circ} \mathrm{C}$ for $6 \mathrm{~h}$, respecitvely. Acid silica gel, basic silica gel were prepared following our previous work (Wang et al., 2012).

\subsection{Sample preparation}

Prior to extraction, the samples were homogenized and freezedried. The extraction and clean-up procedures followed the method reported by Liu et al. (2006). Briefly, $2 \mathrm{~g}$ of plant/reindeer dung or $10 \mathrm{~g}$ of soil was mixed with $10 \mathrm{~g}$ of anhydrous sodium sulfate and spiked with ${ }^{13} \mathrm{C}$-labeled surrogate standards (BDE-LCS and US EPA defined 68A-LCS). The mixture was then extracted on an accelerated solvent extraction device (ASE300, Dionex, USA) using $1: 1 \mathrm{v} / \mathrm{v}$ mixture of $n$-hexane/DCM.

For biota, the extract was concentrated to dryness in order to determine the lipid content and was later redissolved in $50 \mathrm{~mL}$ of $n$-hexane. The solution was then passed through a column packed with acidified silica gel and anhydrous sodium sulfate to remove lipids and moisture, respectively. The resulting eluate was cleaned up with multi-layer silica gel column (packed from bottom to top with $1 \mathrm{~g}$ silica gel, $4 \mathrm{~g}$ basic silica gel, $1 \mathrm{~g}$ silica gel, $8 \mathrm{~g}$ acidic silica gel, $2 \mathrm{~g}$ silica gel, and $4 \mathrm{~g}$ anhydrous sodium sulfate), followed by a basic aluminum column (packed with $6 \mathrm{~g}$ basic alumina and $4 \mathrm{~g}$ anhydrous sodium sulfate at the top) and then a carbon column (1.5 g carbon mixture and $2 \mathrm{~g}$ anhydrous sodium sulfate at the top). The clean eluate was concentrated to $1 \mathrm{~mL}$ using a rotary evaporator and transferred into vials containing $20 \mu \mathrm{L}$ nonane. The contents of the vials were further evaporated to $20 \mu \mathrm{L}$ using a gentle stream of nitrogen and later spiked with injection standards (US EPA defined 68A-IS) prior to instrumental analysis.

\subsection{Instrumental analysis}

The analysis of thirteen PBDE congeners (BDE-17, -28, -47, -66, $-71,-85,-99,-100,-138,-153,-154,-183$ and -190$)$ and twenty-five PCBs congeners including six indicator PCBs (CB-28, -52, -101, $-138,-153$, and -180 ), twelve dioxin-like PCBs (CB-77, -81, -105 , $-114,-118,-123,-126,-156,-157,-167,-169$, and -189), seven other PCBs (CB-3, -11, -15, -202, -205, -208 and -209) were performed using high-resolution gas chromatography coupled with high-resolution mass spectrometry (HRGC/HRMS, AutoSpec Ultima, Waters, USA). The GC working conditions and other instrumental parameters are described in detail by Shang et al. (2013).

Chiral PCBs (CB-95, -136, -149, -174 and -176) were analyzed using a DFS system (Thermo Fisher, USA) with an electron impact (EI) ion source. The HRMS was operated in VSIR mode at a resolution $\geqslant 8000$, source temperature was $250{ }^{\circ} \mathrm{C}$ and electron emission energy was $45 \mathrm{eV}$. Chromatographic separation was achieved by injecting $1 \mu \mathrm{L}$ of sample on a fused silica capillary column (Chirasil-Dex, $30 \mathrm{~m} \times 0.25 \mathrm{~mm}$ i.d. $\times 0.25 \mu \mathrm{m}$ thickness). The temperature conditions of the GC were as follows: initial temperature $60{ }^{\circ} \mathrm{C}$ for $1 \mathrm{~min}$, increased to $150{ }^{\circ} \mathrm{C}$ at $5^{\circ} \mathrm{C} \mathrm{min}^{-1}$, then to $192{ }^{\circ} \mathrm{C}$ at $0.4{ }^{\circ} \mathrm{C} \mathrm{min}{ }^{-1}$, and finally to $220^{\circ} \mathrm{C}$ at $10^{\circ} \mathrm{C} \mathrm{min}{ }^{-1}$. The injection port and transfer line temperature were held at $240^{\circ} \mathrm{C}$. The carrier gas was helium at a constant flow rate of $1.5 \mathrm{~mL} \mathrm{~min}^{-1}$.

\subsection{Quality assurance/quality control ( $Q A / Q C)$}

To ensure quality of the data, a laboratory blank was run after every ten samples. The recoveries based on spiked surrogate standards were $57.4-149 \%$ for PCBs and $63.2-146 \%$ for PBDEs. The limit of detection (LOD) for individual compounds was determined as three times of signal-to-noise ratio $(\mathrm{S} / \mathrm{N})$. The LOD was a function of the extracted mass and varied between analytes (0.01$16.2 \mathrm{pg} \mathrm{g}^{-1} \mathrm{dw}$ for PCBs and 0.03-1.49 $\mathrm{pg} \mathrm{g}^{-1} \mathrm{dw}$ for PBDEs). Several indicator PCBs (CB-28, -52, -101 and-153) and PBDEs (BDE47, -99 and -153 ) were detected in blank samples at relatively low levels ( $<15 \%$ of the levels in samples). Therefore, the detected concentrations of PCBs and PBDEs in samples were not blank corrected.

\subsection{Statistical analysis}

Statistical analysis was performed using SPSS Software for Windows Versions 20 (SPSS, Chicago, IL). The Mann-Whitney U-test was used to determine any significant differences between means of the analytes. Principle component analysis (PCA) was applied to investigate specific PCB congeners contributions between different matrices while one sample T-test was used to test for differences between enantiomeric fractions (EFs) and theoretical EFs of racemic mixtures. EFs were calculated using the equation, $E F s=(+) /$ $[(+)+(-)]$ or EFs $=E_{1} /\left(E_{1}+E_{2}\right)$, where $(+)$ and $(-)$ represent the concentrations of the $(+)$ and $(-)$ enantiomers, and $E_{1}$ and $E_{2}$ represent the first and second eluting enantiomers in GC column (Ross et al., 2008).

\section{Results and discussion}

\subsection{PCBs and PBDEs concentrations}

The mean concentrations of PCBs and PBDEs in different matrices (soils, reindeer dung, mosses and the other five plant species) are presented in Tables 1 and S2. The $\Sigma_{25} \mathrm{PCBs}$ concentrations in soil varied from 0.57 to $2.52 \mathrm{ng} \mathrm{g}^{-1}$ dry weight (dw). They were consistent with those in the same region reported by Jartun et al. (2010) (4.2 $\mathrm{ng} \mathrm{g}^{-1} \mathrm{dw}$ ) and in background surface soil from Svalbard (Kallenborn et al., 2013) (1-5 $\left.\mathrm{ng} \mathrm{g}^{-1} \mathrm{dw}\right)$, but lower than those in the Canadian Arctic (Pier et al., 2002) and United Kingdom and Norway (Meijer et al., 2002) (Table S3). Different PCB concentrations in soils were observed at seven sampling sites (Fig. S1),

Table 1

Mean concentrations of $\sum_{25} \mathrm{PCBs}\left(\mathrm{ng} \mathrm{g}^{-1} \mathrm{dw}\right)$ and $\sum_{13} \mathrm{PBDEs}\left(\mathrm{pg} \mathrm{g}^{-1} \mathrm{dw}\right)$ in different samples.

\begin{tabular}{lll}
\hline & $\sum_{25} \mathrm{PCBs}$ & $\sum_{13} \mathrm{PBDEs}$ \\
\hline Moss (Drepanocladus aduncus) & $0.75(0.43-1.16)^{\mathrm{a}}$ & $119(36.7-495)$ \\
Mountain avens (Dryas octopetala) & $0.49(0.42-0.58)$ & $45.7(42.1-48.1)$ \\
Arctic bell-heather (Cassiope tetragona) & $0.57(0.48-0.63)$ & $70.1(42.2-121)$ \\
Sooty sedge (Carex misandra) & $0.45(0.3-0.55)$ & $80(54.7-111)$ \\
Alpine hair grass (Deschampsia alpine) & $0.41(0.37-0.46)$ & $74.4(73.4-75.3)$ \\
Tufted saxifrage (Saxifraga cespitosa) & 0.37 & 41.9 \\
Reindeer dung & $0.77(0.56-0.98)$ & $52(28.1-104)$ \\
Soil & $1.38(0.57-2.52)$ & $65.5(1.7-416)$ \\
\hline
\end{tabular}

${ }^{\text {a }}$ Arithmetic mean, minimum and maximum concentrations are listed. 
and they were significantly higher than those in plants $(p<0.05$, Mann-Whitney U-test).

The $\Sigma_{25}$ PCBs levels in moss (D. aduncus) varied from 0.39 to $1.02 \mathrm{ng} \mathrm{g}^{-1} \mathrm{dw}$, comparable to those in the same region reported by Ma et al. (2008) (0.92-1.97 $\mathrm{ng} \mathrm{g}^{-1} \mathrm{dw}$ ), and in moss (Sanionia uncinata) (0.41-0.95 $\mathrm{ng} \mathrm{g}^{-1} \mathrm{dw}$ ) from King George Island and Ardley Island in the Antarctica (Wang et al., 2012). PCBs levels in reindeer dung were $0.56-0.98 \mathrm{ng} \mathrm{g}^{-1} \mathrm{dw}$, equally distributed at different sampling sites (Fig. S1). The $\Sigma_{25} \mathrm{PCBs}$ in D. alpine, D. octopetala, $C$. tetragona, $C$. misandra and $S$. cespitosa were $0.37-0.46$, $0.42-0.58,0.48-0.63,0.30-0.55$ and $0.37 \mathrm{ng} \mathrm{g}^{-1} \mathrm{dw}$, respectively (Tables 1 and S2).

The $\sum_{13}$ PBDEs concentrations in soil ranged from 1.7 to $416 \mathrm{pg} \mathrm{g}^{-1} \mathrm{dw}$. They were lower than those reported in Norway (Hassanin et al., 2004), and the Antarctica (Cipro et al., 2011), but in the same levels with those from Canada (Danon-Schaffer et al., 2007) (Table S3). Although PCBs in soils were higher than those in $D$. aduncus, the reverse trend was found for PBDEs (Table 1). The $\sum{ }_{13}$ PBDEs levels in $D$. aduncus varied from 36.7 to $118 \mathrm{pg} \mathrm{g}^{-1}$ $\mathrm{dw}$ with an outlier at site 6 (Fig. S1). These data were in the same range as those in mosses (Sanionia uncinata, Syntrichia princeps, Brachythecium sp.) from King George Island in the Antarctica (Cipro et al., 2011; Yogui et al., 2011), and comparable to those in H. splendens from Norway (Mariussen et al., 2008) and S. uncinat$a$ from the Antarctica reported by Wang et al. (2012) (Table S3). The $\sum{ }_{13}$ PBDEs concentrations were 28.1 to $104 \mathrm{pg} \mathrm{g}^{-1} \mathrm{dw}$ in reindeer dung, 73.4-75.3 $\mathrm{pg} \mathrm{g}^{-1} \mathrm{dw}$ in D. alpine, 42.1-48.1 $\mathrm{pg} \mathrm{g}^{-1} \mathrm{dw}$ in D. octopetala, $42.2-121 \mathrm{pg} \mathrm{g}^{-1} \mathrm{dw}$ in C. tetragona, $54.7-111 \mathrm{pg} \mathrm{g}^{-1}$ $\mathrm{dw}$ in C. misandra, $41.9 \mathrm{pg} \mathrm{g}^{-1} \mathrm{dw}$ in $S$. cespitosa, respectively (Tables 1 and S2).

\subsection{Congener profiles of PCBs and PBDEs}

Most of the 25 PCB congeners were detected in all samples except CB-15, $-81,-169$, and -189 . CB-11 was the predominant congeners in most samples, which contributed $26.2 \pm 8.4 \%$ to the $\sum_{25}$ PCBs in reindeer dung and $31.7 \pm 7.6 \%$ in D. alpine. $\mathrm{CB}-11$ was observed in water, suspended particulate material, and mussel tissues in Halifax Harbor (King et al., 2002) and in the air of Chicago (Hu et al., 2010). High levels of CB-11 were also reported in air samples in Ny-Ålesund, Arctic (Choi et al., 2008), air, soil, sediment, moss and lichen in King George Island, West Antarctica (Li et al., 2012; Wang et al., 2012). The abundant CB-11 in the present study was different to explain, and further investigations are required to reveal unidentified global sources. CB-28, $-101,-138$ and -153 were also the dominating PCB congeners, which accounted for $41.6-70.5 \%$ to the $\sum_{25} \mathrm{PCBs}$ in all samples. The primary sources of PCBs in the Arctic could be associated with long-range atmospheric transport and global fractionation (King et al., 2002; Choi et al., 2008).

The homologue profiles of PCBs were different between plants and soils, especially for the low chlorinated homologue (Fig. 2a). The dominant PCB homologues in plants were mono- to hexa$\mathrm{CBs}$, whereas high proportions of tetra- and hexa-CBs were observed in soil. For instance, mono-CBs accounted for about $3.7 \%$ to the $\sum$ PCBs in plants and $0.7 \%$ in soil. Varied homologue profiles could be attributed to different accumulation routes. Soil accumulates POPs mainly through dry and wet deposition of particles, whereas apart from these routes, POPs in plants could also come from accumulation and transport from soil, and gaseous deposition to leaf via cuticle and stomata (Collins et al., 2005; Wang et al., 2009). Tetra-CBs represented $49.9 \%$ of the $\sum$ PCBs in $S$. cespitosa, whereas it was not the case for soil, $D$. aduncus and reindeer dung at different sampling sites (Fig. S2). The higher chlorinated homologues were detected at low levels in all samples, indicating that they are not easily transported to high latitudes by atmospheric deposition (Sericano et al., 2001; Choi et al., 2008).

The dominant PBDE congeners were BDE-47, -99 and -183 , accounting for $51.2 \%, 17.8 \%$ and $7.9 \%$ to the $\sum_{13} \mathrm{PBDE}$, respectively (Fig. 2b). The high percentage of BDE-47 and -99 (69\%) was compatible with commercial penta-BDEs products, such as Bromkal $70-5 D E$, in which BDE-47 and -99 cover $72 \%$ of its formulation (Hassanin et al., 2004). The BDE-47/99 ratio in this study was $3.45 \pm 1.52,1.53 \pm 0.27$ and $1.92 \pm 0.47$ in soils, D. aduncus and reindeer dung, respectively, which were higher than those in commercial products (1:1 in Bromkal 70-5DE). This deviation could be due to the global distillation of these compounds through longrange transport (Lead et al., 1996). Another probable reason might be environmental debromination along congener pathways BDE$154 \rightarrow$ BDE-99 $\rightarrow$ BDE-47 (Ikonomou et al., 2002). The proportion of BDE-183 was relatively high in soil samples at S2 and S4 (80.0\% and 60.9\%), D. aduncus at S6 (77.6\%) and reindeer dung at S4 (36.3\%) (Fig. S3). Penta-BDE, octa-BDE, and deca-BDE are used in a wide range of materials as technical PBDEs mixtures (Ikonomou et al., 2002), and BDE-183 is considered a marker congener of the octa-BDE products (Hassanin et al., 2004). The higher proportion of BDE-183 indicated the existence of a local pollution source.

\subsection{Principal component analysis (PCA) of PCBs}

In this study, principal component analysis (PCA) was carried out to investigate the specific $\mathrm{PCB}$ congeners partitioned in various environmental matrices. The first and second components (PC1
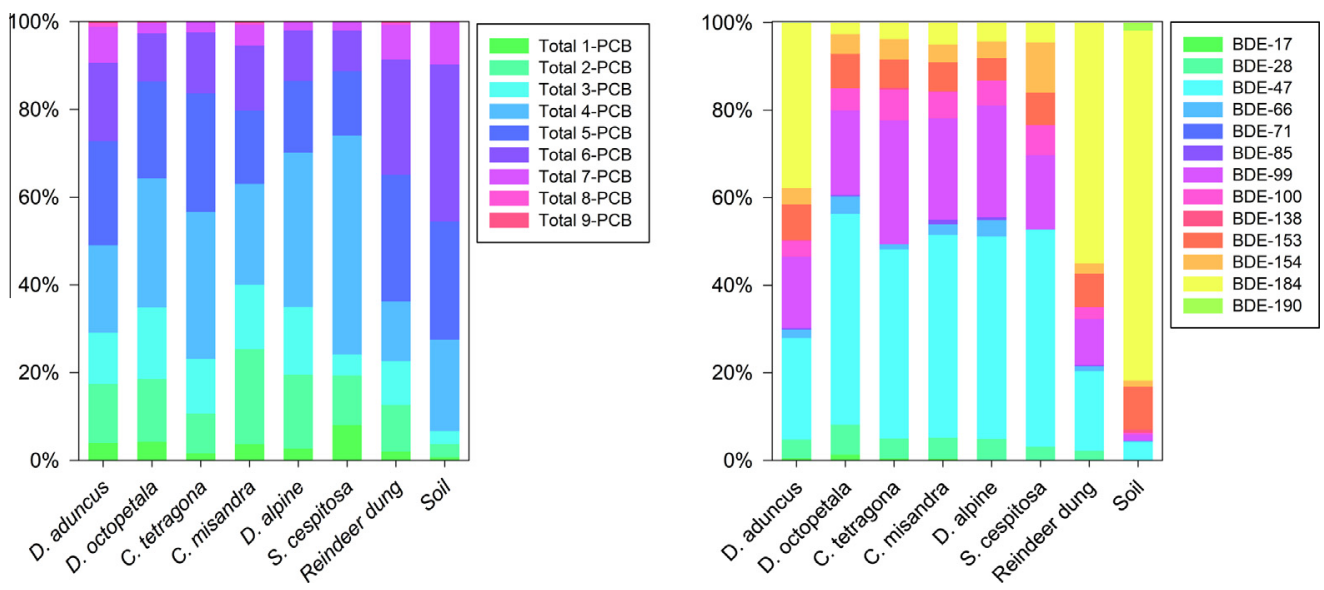

Fig. 2. Congener profiles of PCBs and PBDEs in different samples. 

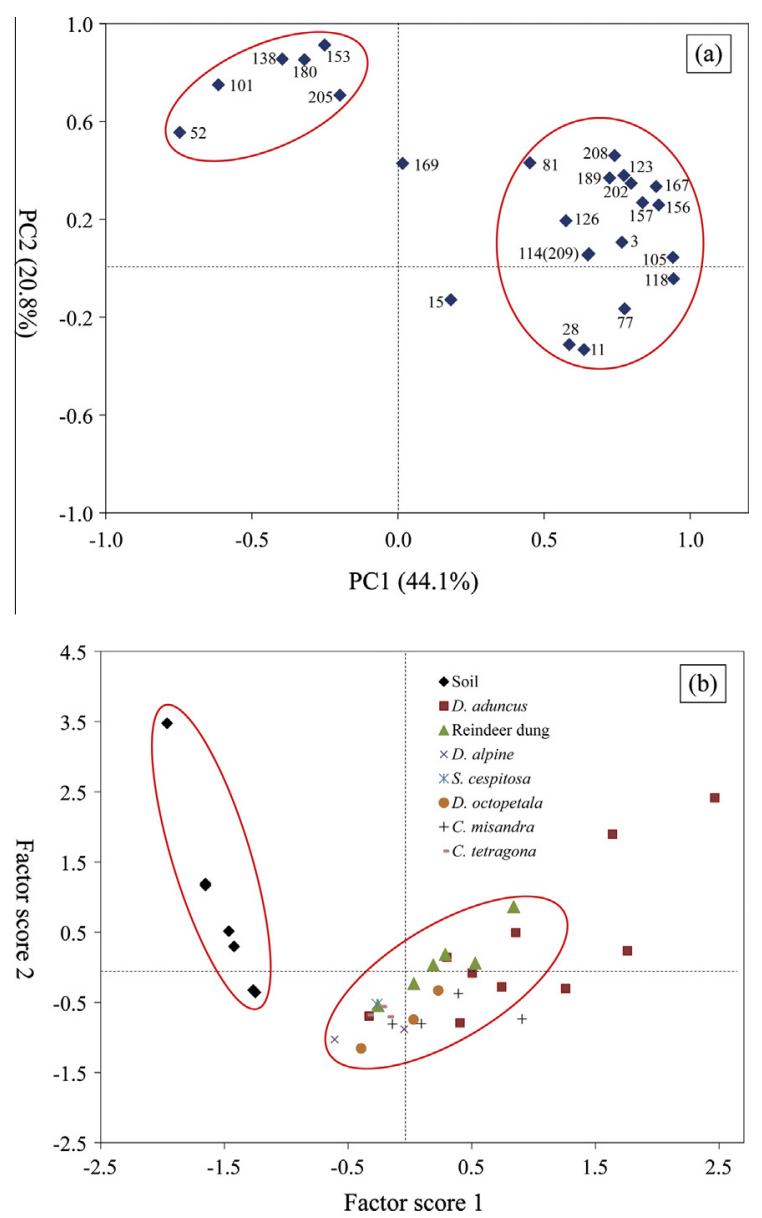

Fig. 3. Loading (a) and scores (b) plots of principal component analysis (PCA) for individual $\mathrm{PCB}$ congeners. The circles represent similar cluster conditions and scores.

and PC2) described 44.1 and $20.8 \%$ of the total variance. Loading plots of PCA revealed that 25 PCB congeners were clearly separated into two clusters: the upper-left cluster including five indicator PCBs (CB-52, -101, -138, -153 and -180) and CB-205, and the other one consisted of eleven dl-PCBs (except CB-169) and some other PCBs (Fig. 3a). Based on score plots of PCA (Fig. 3b), it was observed that soils and plants had markedly variant scores on PC1 and PC2. Percentage of the five indicator PCBs and CB-205 to $\sum_{25}$ PCBs in soils $(87.8 \%$, range $76.8-94.8 \%$ ) was greatly higher than those in plants (49.2\%, range $29.8-72.9 \%$ ). The contributions of dl-PCBs to $\sum_{25} \mathrm{PCBs}$ were 0.21 and $7.5 \%$ in soils and plants, respectively. These varied congener distributions between soils and plants could be explained by the different accumulation routes of PCBs (Collins et al., 2005; Wang et al., 2009). As discussed above, the PCA results provide a visual display on different congener distributions in analyzed environmental samples.

\subsection{Chiral signatures of PCBs}

Chiral PCBs could modulate the stereochemical ratio between enantiomers in environmental biota, which are regarded as good molecular indicators of biological metabolic processes, and usually be assessed using enantiomeric fraction (EFs) (Moisey et al., 2001; Fisk et al., 2002; Zhai et al., 2011). In the present study, five chiral PCBs (CB-95, -136, -149, -174 and -176) were investigated and they were detected in all analyzed environmental matrices (soil, reindeer dung and six plant species) except for CB-174 in reindeer

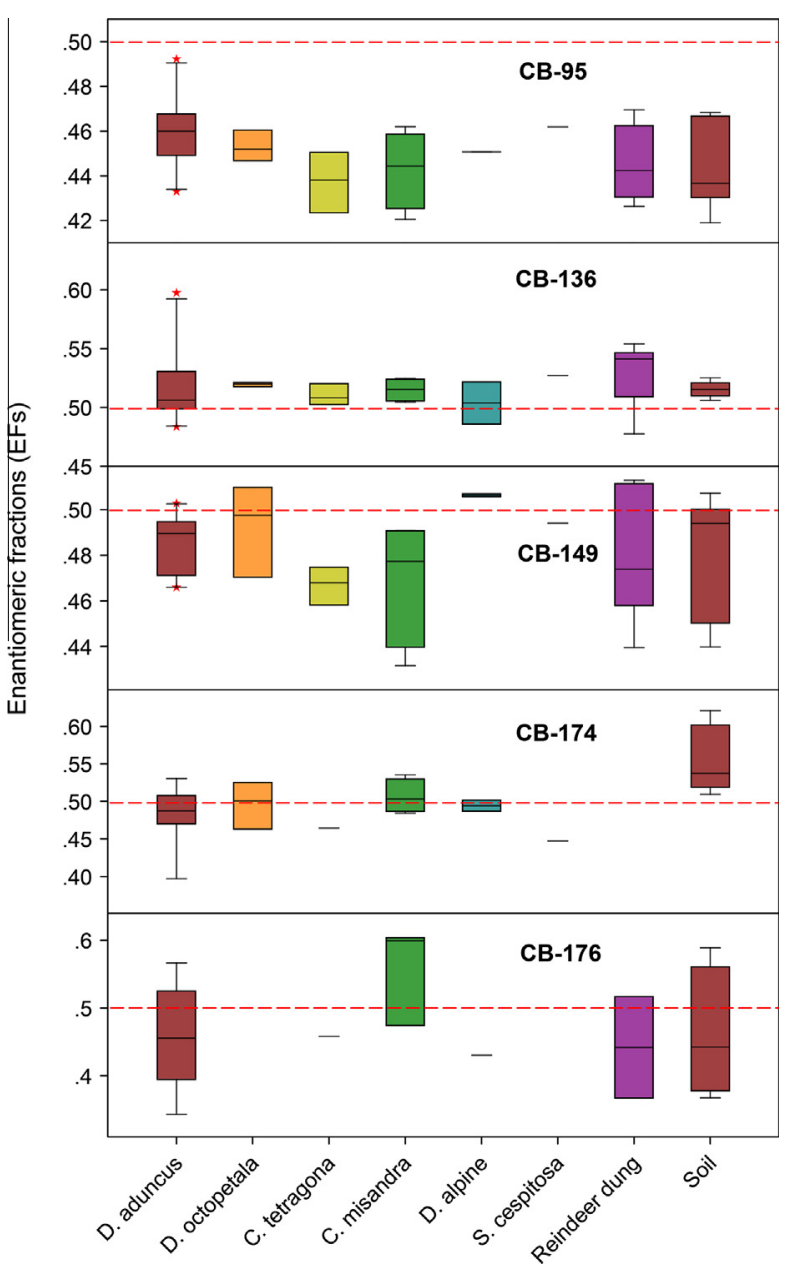

Fig. 4. Enantiomeric fractions (EFs) of five chiral PCBs in different samples. Red dash line represents the theoretical $\mathrm{EF}(0.5)$ of racemic mixtures. (For interpretation of the references to color in this figure legend, the reader is referred to the web version of this article.)

dung and CB-176 in D. octopetala. The mean EF values fluctuated around theoretical EF value of racemic mixtures of 0.5 (Fig. 4).

The EFs of CB-95 in all matrices were greatly lower than 0.5 , indicating nonracemic signatures and enrichment of the secondeluted enantiomer or $(-)$ enantiomer. Similar enantioselective biotransformation of CB-95 was also reported in poplars (Populus deltoides) after 20 days exposure (Zhai et al., 2011). The EF values of CB-136 in analyzed matrices were slightly higher than 0.5 , but the consistent results between soils and plants were not observed for other chiral PCBs. The EFs of CB-174 in soil $(0.555 \pm 0.044)$ were significantly higher than those in $D$. aduncus $(\mathrm{EF}=0.485 \pm 0.039$, $p=0.011)$ and $D$. alpine $(\mathrm{EF}=0.495 \pm 0.011, p=0.023)$. They were also significantly higher than those in racemic mixtures, suggesting that CB-174 in soil showed enantioselective degradation. These results are consistent with EFs of CB-95, -149 and -174 in background soils collected in the United Kingdom and Norway (Schuster et al., 2011). Non-racemic EFs of CB-95, -136, and -149 were also found in top soils in the United Kingdom and Canada (Lehmler et al., 2009). Compared with CB-95, chiral PCBs with large molecular weight (such as CB-136, -174 and -176) presented nearly racemic or slightly enantioselective biotransformation. Chiral CB-95 was more easily enantioselectively biotransformed than other chiral PCBs in soils and plants. This result could be ascribed to the decreasing metabolism rates of PCBs with ascending molecular mass and compound-specific reactions with different enzymes or other biochemical processes (Zhai et al., 2011). 
In short, the signature of enantioselective biotransformation was observed in all samples for CB-95, in soil, reindeer dung, $C$. misandra, and C. tetragona for CB-136, in C. tetragona, and S. cespitosa for CB-149 and in soil for CB-174 (Fig. 4). These varied signatures could be contributed to microbial enantioselective transformation by microorganisms in soil, and selective absorption in organisms (Zhai et al., 2011). Some other complex factors, such as soil organic carbon, organic matter and $\mathrm{pH}$ could also influence enantioselective degradation in environmental matrices (Bidleman et al., 2012).

\subsection{Bioaccumulation in plants}

Bioaccumulation factors (BAFs) were calculated from the ratio of contaminant concentrations in plant to those in soils. In this paper, BAF values of $\sum_{25} \mathrm{PCBs}$ in six plant species were lower than 1 , ranging from 0.28 in D. alpine to 0.71 in D. aduncus (Table S3). Similarly, lower BAFs were also observed for CB-52 and -101 in D. aduncus, CB-52, $-101,-138,-153,-180$ and -250 in plant species except for $D$. aduncus. The BAFs for CB-28, CB-118 and other PCB congeners were higher than 1 . For example, $\mathrm{CB}-28$ in plants varied from 2.89 in $S$. cespitosa to 9.93 in D. octopetala. All the BAF values of PCBs in this study were consistent with those in Arctic vascular plants comprising 31 genera from Canadian Arctic and Subarctic (Pier et al., 2002). The bioaccumulation trends were observed for $\sum$ PBDEs, increasing in the order of $S$. cespitosa (BAF: 2.41$)<D$. octopetala $(7.93)<C$. tetragona $(8.13)<C$. misandra $(18.8)<D$. aduncus $(26.2)<D$. alpine (44.3) (Table S3).

Plants physiology (such as water, lipid, carbohydrate and fiber content) and morphology characteristics (leaves, stems, or bark), physical-chemical properties of contaminants $\left(K_{\mathrm{OW}}\right.$ or $\left.K_{\mathrm{OA}}\right)$ and different sampling sites with different rhizosphere in soil could account for the variant BAFs (Collins et al., 2005; Vrkoslavová et al., 2010). D. aduncus reported higher BAFs of PCBs because they have one-cell thick leaves, covering a thin stem, and do not have vascular tissue which could enhance them to take up contaminants from the surrounding environments. Low BAFs in D. alpine and $S$. cespitosa could be ascribed to their morphological characteristics or contaminants redistribution through active translocation (Pier et al., 2002).

A bell-shaped correlation $\left(R^{2}=0.46, p<0.006\right)$ was observed between BAFs and $K_{\mathrm{OW}}$ of PCBs, with the maximum BAF corresponding to hexa-CBs with $\log K_{\mathrm{OW}}$ values of 7.2-7.6 (Fig. 5). This result may be explained by the fact that lower chlorinated PCBs are easily metabolized by plants, whereas higher chlorinated PCBs with large $K_{\mathrm{OW}}$ are more tightly bound to the soils and less available for plants uptake (Pier et al., 2002). With regard to PBDEs, a slightly declining trend was observed in the present study with the increase of number of bromine atoms. Vrkoslavová et al. (2010) reported BAFs value of BDE-47, -99, -100 and -209 negatively correlated with their $\log K_{\mathrm{OW}}$ in tobacco (Nicotiana tabacum) and nightshade (Solanum nigrum), which was consistent with the result in this study. A negative correlation was also observed between BAFs and $\log K_{\mathrm{OW}}$ values from paddy soils to rice plant (She et al., 2013). The descending BAFs for PBDE congeners with high $K_{\mathrm{OW}}$ could be due to hydrophobicity and large molecular weight, which restricted contaminant penetration into cellular membranes (She et al., 2013).

Log-transformed BAFs exhibited significantly negative correlations to log-transformed PCBs concentration in soil $\left(R^{2}=0.73\right.$, $p<0.0001)$ and log-transformed PBDEs concentration in soil $\left(R^{2}=0.91, p<0.0001\right)$ (Fig. S4). Similar trends was also reported by Pier et al. (2002), who indicated that BAFs of vascular plants in the Canadian Arctic and Subarctic negatively correlated with PCBs concentration in soil $\left(R^{2}=0.55\right)$. Low BAFs of PCBs and PBDEs corresponded to high contaminant levels in soil, which suggested
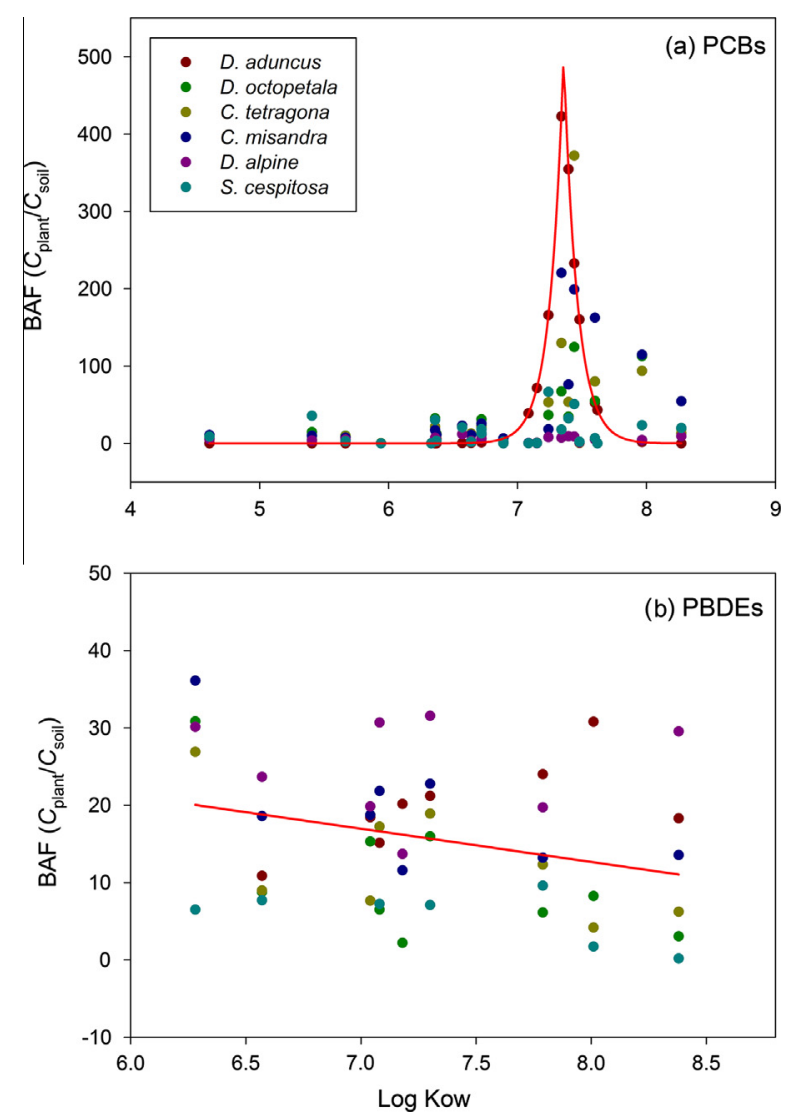

Fig. 5. Relationships between BAFs and $\log K_{\mathrm{OW}}$ values for PCB (a) and PBDE (b). Those BAFs corresponding to congeners whose concentrations were lower than limit of detection were not shown.

that high background levels of contaminants in soil could restrict the accumulation of these contaminants by plants (Pier et al., 2002). This could also explain why reverse variation trend of PCBs and PBDEs levels in the present study existed between soils and plants.

\section{Conclusions}

The present study examined the current contamination levels, distributions, homologue profiles and bioaccumulation of PCBs and PBDEs in plants and soil samples from the London Island, Svalbard, the Arctic. The results revealed that the current concentrations of PCBs and PBDEs were low on the global scale and they were not evidently affected by research stations in Ny-Ålesund. The mean concentrations of PCBs in soils were higher than those in plants. However, the reverse trend was observed for PBDEs. CB-11, -28, -101, -138 and -153 were the dominated PCB congeners, and BDE-47 was predominant for PBDEs. Chiral CB-95 in all analyzed matrices presented accordant enantioselectivity biotransformation, and varied enantioselectivity between matrices was observed for other chiral PCBs. Bioaccumulation factors of PCBs and PBDEs varied within different contaminant congeners and plant species. Further research is needed to better understand the enantioselectivity and bioaccumulation properties of these contaminants in the Arctic environment.

\section{Acknowledgements}

This study was jointly funded by National Natural Science Foundation of China (41276195, 21477155 and 21277165), Young Scientists Fund of RCEES (RCEES-QN-20130005F), Chinese Academy 
of Sciences (XDB14010100 and YSW2013B01) and the State Oceanic Administration, P.R. China (2011YR07007 and 2012YR16016). We also thank Chinese Arctic and Antarctic Ministration for the arrangements during the Chinese Arctic Scientific Expedition in 2011 and 2012.

\section{Appendix A. Supplementary material}

Supplementary data associated with this article can be found, in the online version, at http://dx.doi.org/10.1016/j.chemosphere. 2015.01.043.

\section{References}

Bidleman, T.F., Jantunen, L.M., Kurt-Karakus, P.B., Wong, F., 2012. Chiral persistent organic pollutants as tracers of atmospheric sources and fate: review and prospects for investigating climate change influences. Atmos. Pollut. Res. 3, 371-382.

Braune, B.M., Mallory, M.L., Grant Gilchrist, H., Letcher, R.J., Drouillard, K.G., 2007. Levels and trends of organochlorines and brominated flame retardants in ivory gull eggs from the Canadian Arctic, 1976 to 2004. Sci. Total Environ. 378, 403417.

Choi, S.D., Baek, S.Y., Chang, Y.S., Wania, F., Ikonomou, M.G., Yoon, Y.J., Park, B.K., Hong, S., 2008. Passive air sampling of polychlorinated biphenyls and organochlorine pesticides at the Korean Arctic and Antarctic research stations: implications for long-range transport and local pollution. Environ. Sci. Technol. 42, 7125-7131.

Cipro, C.V.Z., Yogui, G.T., Bustamante, P., Taniguchi, S., Sericano, J.L., Montone, R.C., 2011. Organic pollutants and their correlation with stable isotopes in vegetation from King George Island, Antarctica. Chemosphere 85, 393-398.

Collins, C., Fryer, M., Grosso, A., 2005. Plant uptake of non-ionic organic chemicals. Environ. Sci. Technol. 40, 45-52.

Corsolini, S., Kannan, K., Imagawa, T., Focardi, S., Giesy, J.P., 2002. Polychloronaphthalenes and other dioxin-like compounds in Arctic and Antarctic marine food webs. Environ. Sci. Technol. 36, 3490-3496.

Dang, V.D., Walters, D.M., Lee, C.M., 2010. Transformation of chiral Polychlorinated Biphenyls (PCBs) in a stream food web. Environ. Sci. Technol. 44, 2836-2841.

Danon-Schaffer, M.N., Gorgy, T., Li, L., Grace, J.R., 2007. Determination of PBDEs in Canadian North landfill leachate and soils. Final Report - September 2007. University of British Columbia, p. 139.

de Wit, C.A., Alaee, M., Muir, D.C.G., 2006. Levels and trends of brominated flame retardants in the Arctic. Chemosphere 64, 209-233.

de Wit, C.A., Herzke, D., Vorkamp, K., 2010. Brominated flame retardants in the Arctic environment - trends and new candidates. Sci. Total Environ. 408, 2885 2918.

Fisk, A.T., Holst, M., Hobson, K.A., Duffe, J., Moisey, J., Norstrom, R.J., 2002. Persistent organochlorine contaminants and enantiomeric signatures of chiral pollutants in ringed seals (Phoca hispida) collected on the east and west side of the Northwater Polynya, Canadian Arctic. Arch. Environ. Contam. Toxicol. 42, 118126.

Hargrave, B.T., Phillips, G.A., Vass, W.P., Bruecker, P., Welch, H.E., Siferd, T.D., 2000. Seasonality in bioaccumulation of organochlorines in lower trophic level arctic marine biota. Environ. Sci. Technol. 34, 980-987.

Hassanin, A., Breivik, K., Meijer, S.N., Steinnes, E., Thomas, G.O., Jones, K.C., 2004. PBDEs in European background soils: levels and factors controlling their distribution. Environ. Sci. Technol. 38, 738-745.

Herzke, D., Gabrielsen, G.W., Evenset, A., Burkow, I.C., 2003. Polychlorinated camphenes (toxaphenes), polybrominated diphenylethers and other halogenated organic pollutants in glaucous gull (Larus hyperboreus) from Svalbard and Bjornoya (Bear Island). Environ. Pollut. 121, 293-300.

Hu, D., Hornbuckle, K.C., 2010. Inadvertent polychlorinated biphenyls in commercial paint pigments. Environ. Sci. Technol. 44, 2822-2827.

Ikonomou, M.G., Rayne, S., Addison, R.F., 2002. Exponential increases of the brominated flame retardants, polybrominated diphenyl ethers, in the Canadian arctic from 1981 to 2000. Environ. Sci. Technol. 36, 1886-1892.

Jansson, B., Asplund, L., Olsson, M., 1987. Brominated flame retardants - ubiquitous environmental pollutants? Chemosphere 16, 2343-2349.

Jartun, M., Eggen, O.A., Tore, R., 2010. PCBs from local sources in Svalbard - surface soil and products 2007-2009. The Governor of Svalbard and the Climate and Pollution Agency (Klif).

Kallenborn, R., Ottesen, R.T., Gabrielsen, G.W., Schrum, C., Evennset, A., Ruus, A., Benjaminsen, H., Sagerup, K., Christensen, G., Eggen, O., Carlsson, P., JohanssonKarlsson, E., Polder, A., Pedersen, H.R., Lundkvist, Q., 2013. PCB on Svalbard Report 2011. The Governor of Svalbard.

King, T.L., Yeats, P., Hellou, J., Niven, S., 2002. Tracing the source of 3,3'dichlorobiphenyl found in samples collected in and around Halifax Harbour. Mar. Pollut. Bull. 44, 590-596.
Lead, W.A., Steinnes, E., Jones, K.C., 1996. Atmospheric deposition of PCBs to moss (Hylocomium splendens) in Norway between 1977 and 1990. Environ. Sci. Technol. 30, 524-530.

Lehmler, H.J., Harrad, S.J., Hühnerfuss, H., Kania-Korwel, I., Lee, C.M., Lu, Z., Wong, C.S., 2009. Chiral polychlorinated biphenyl transport, metabolism, and distribution: a review. Environ. Sci. Technol. 44, 2757-2766.

Li, Y.M., Geng, D.W., Liu, F.B., Wang, T., Wang, P., Zhang, Q.H., Jiang, G.B., 2012. Study of PCBs and PBDEs in King George Island, Antarctica, using PUF passive air sampling. Atmos. Environ. 51, 140-145.

Liu, H.X., Zhang, Q.H., Cai, Z.W., Li, A., Wang, Y.W., Jiang, G.B., 2006. Separation of polybrominated diphenyl ethers, polychlorinated biphenyls, polychlorinated dibenzo-p-dioxins and dibenzo-furans in environmental samples using silica gel and florisil fractionation chromatography. Anal. Chim. Acta 557, 314-320.

Ma, X.D., Wang, Y.J., Na, G.S., Lin, Z.S., Zhou, C.G., Wang, Z., Yao, Z.W., 2008 Distribution of organochlorine pesticides and polychlorinated biphenyls in NyÅlesund of Arctic area. Chin. J. Polar Res. 20, 329-337 (in Chinese).

Mariussen, E., Steinnes, E., Breivik, K., Nygård, T., Schlabach, M., Kålås, J.A., 2008 Spatial patterns of polybrominated diphenyl ethers (PBDEs) in mosses herbivores and a carnivore from the Norwegian terrestrial biota. Sci. Total Environ. 404, 162-170.

McDonald, T.A., 2002. A perspective on the potential health risks of PBDEs. Chemosphere 46, 745-755.

McKinney, M.A., Letcher, R.J., Aars, J., Born, E.W., Branigan, M., Dietz, R., Evans, T.J., Gabrielsen, G.W., Peacock, E., Sonne, C., 2011. Flame retardants and legacy contaminants in polar bears from Alaska, Canada, East Greenland and Svalbard 2005-2008. Environ. Int. 37, 365-374.

Meijer, S.N., Steinnes, E., Ockenden, W.A., Jones, K.C., 2002. Influence of environmental variables on the spatial distribution of PCBs in Norwegian and U.K. soils: implications for global cycling. Environ. Sci. Technol. 36, 2146-2153.

Moisey, J., Fisk, A.T., Hobson, K.A., Norstrom, R.J., 2001. Hexachlorocyclohexane $(\mathrm{HCH})$ isomers and chiral signatures of $\alpha-\mathrm{HCH}$ in the Arctic marine food web of the Northwater Polynya. Environ. Sci. Technol. 35, 1920-1927.

Muir, D.C.G., Norstrom, R.J., 2000. Geographical differences and time trends of persistent organic pollutants in the Arctic. Toxicol. Lett. (Shannon), 93-101.

Negoita, T.G., Covaci, A., Gheorghe, A., Schepens, P., 2003. Distribution of polychlorinated biphenyls (PCBs) and organochlorine pesticides in soils from the East Antarctic coast. J. Environ. Monitor. 5, 281-286.

Ockenden, W.A., Breivik, K., Meijer, S.N., Steinnes, E., Sweetman, A.J., Jones, K.C. 2003. The global re-cycling of persistent organic pollutants is strongly retarded by soils. Environ. Pollut. 121, 75-80.

Pier, M.D., Zeeb, B.A., Reimer, K.J., 2002. Patterns of contamination among vascular plants exposed to local sources of polychlorinated biphenyls in the Canadian Arctic and Subarctic. Sci. Total Environ. 297, 215-227.

Ross, M.S., Verreault, J., Letcher, R.J., Gabrielsen, G.W., Wong, C.S., 2008. Chira organochlorine contaminants in blood and eggs of glaucous gulls (Larus hyperboreus) from the Norwegian Arctic. Environ. Sci. Technol. 42, 7181-7186.

Schuster, J.K. Gioia, R., Moeckel, C. Agarwal, T, Bucheli, T.D. Breivik, K. Steinnes, E. Jones, K.C., 2011. Has the burden and distribution of PCBs and PBDEs changed in European background soils between 1998 and 2008? Implications for sources and processes. Environ. Sci. Technol. 45, 7291-7297.

Sericano, J.L., Brooks, J.M., Champ, M.A., Kennicutt, M.C., Makeyev, V.V., 2001. Trace contaminant concentrations in the Kara Sea and its adjacent rivers, Russia. Mar. Pollut. Bull. 42, 1017-1030.

Shang, H.T., Wang, P., Wang, T., Wang, Y.W. Zhang, H.D., Fu, J.J., Ren, D.W., Chen, W.H., Zhang, Q.H., Jiang, G.B., 2013. Bioaccumulation of PCDD/Fs, PCBs and PBDEs by earthworms in field soils of an E-waste dismantling area in China. Environ. Int. 54, 50-58.

Shang, H.T., Li, Y.M., Wang, T., Wang, P., Zhang, H.D., Zhang, Q.H., Jiang, G.B., 2014 The presence of polychlorinated biphenyls in yellow pigment products in China with emphasis on 3,3'-dichlorobiphenyl (PCB 11). Chemosphere 98, 44-50.

She, Y.Z., Wu, J.P., Zhang, Y., Peng, Y., Mo, L., Luo, X.J., Mai, B.X., 2013. Bioaccumulation of polybrominated diphenyl ethers and several alternative halogenated flame retardants in a small herbivorous food chain. Environ. Pollut. $174,164-170$.

Vrkoslavová, J., Demnerová, K., Macková, M., Zemanová, T., Macek, T., Hajšlová, J. Pulkrabová, J., Hrádková, P., Stiborová, H., 2010. Absorption and translocation of polybrominated diphenyl ethers (PBDEs) by plants from contaminated sewage sludge. Chemosphere 81, 381-386.

Wang, Z., Ma, X.D., Na, G.S., Lin, Z.S., Ding, Q., Yao, Z.W., 2009. Correlations between physicochemical properties of PAHs and their distribution in soil, moss and reindeer dung at Ny-Ålesund of the Arctic. Environ. Pollut. 157, 3132-3136.

Wang, P., Zhang, Q.H., Wang, T., Chen, W.H., Ren, D.W., Li, Y.M., Jiang, G.B., 2012 PCBs and PBDEs in environmental samples from King George Island and Ardley Island, Antarctica. RSC Adv. 2, 1350-1355.

Yogui, G.T. Sericano, J.L., 2008. Polybrominated diphenyl ether flame retardants in lichens and mosses from King George Island, maritime Antarctica. Chemosphere 73, 1589-1593.

Yogui, G.T., Sericano, J.L., Montone, R.C., 2011. Accumulation of semivolatile organic compounds in Antarctic vegetation: a case study of polybrominated diphenyl ethers. Sci. Total Environ. 409, 3902-3908.

Zhai, G.S., Hu, D.F., Lehmler, H.J., Schnoor, J.L., 2011. Enantioselective biotransformation of chiral PCBs in whole poplar plants. Environ. Sci. Technol $45,2308-2316$. 